\title{
Animal performance and plant production from continu- ously grazed cool-season reclaimed and native pastures
}

\author{
L. HOFMANN AND R.E. RIES
}

\section{Abstract}

The Surface Mining Control and Reclamation Act of 1977 requires that surface-mined land be revegetated with "the same seasonal variety", meaning apecies of the same season of growth as the species native to the area. Our objective was to compare seasonof-grazing use of pastures comprised of introduced cool-season species with pastures comprised of a mix of native warm- and cool-season species. The study was conducted on surface-mined land near Center, North Dakota, dominated by smooth bromegrass (Bromus inermis Leyss.) and alfalifa (Medicago sativa $L$.) and on adjacent unmined mixed prairie. Pastures were 1.86 ha in size and stocked with 2 yearling steers (Bos spp.) each. Graxing was started in May or June and ended in late September or early October for 96 days in 1982 and 126 days each in 1983, 1984, and 1985. Liveweight gain increased from mid June through August and then remained constant on all pastures. Herbage dry matter yield from reclaimed pastures was equal to or greater than yield from native pustures each year. The season-of-grazing use was no different for reclaimed cool-season pastures than for native mixed prairie, and there was no evidence that species with the same growing season as those native to the area were necessary to provide season-long grazing use. Cool-season forage species are easier to seed, establish, and less expensive to buy and can be used to revegetate surface-mined land for season-long grazing use.

Key Words: surface-mined land, warm-season species, ground cover, species composition, liveweight gain, herbage dry matter

In the northern Great Plains, most of the native grasslands contain a mixture of cool- and warm-season grass, legume, and forb species and generally provide season-long-grazing use. Surfacemined land can be revegetated at less expense and most easily with cool-season introduced plant species, but there is general concern that these species will not provide season-long-grazing use. This is the primary reason that the Surface Mining Control and Reclamation Act of 1977 (The Act), Public Law 95-87, required that the permanent vegetative cover establishment should be "of the same seasonal variety native to the area of land to be affected"[Sec. 515 . (b) (19)].

Barker et al. (1977) found that cool-season species, especially the more commonly used introduced species, were much easier to establish than warm-season species on mined land. DePuit (1982) and Ries (1982) summarized the use of cool-season and warmseason perennial grasses, respectively, for revegetation of mined land in the northern Great Plains. The greater ease of revegetating with cool-season perennial grass species than with warm-season grasses also was apparent from these papers, and indicated that similar "seasonal variety" may be one of the most difficult criteria to attain.

DePuit et al. (1980) established a predominantly native plant

\footnotetext{
Authors are agronomist and range scientist, Northern Great Plains Research Laboratory, P.O. Box 459, Mandan, North Dakota 58554.

Contribution from Northern Great Plains Research Laboratory, USDA-ARS. Manuscript accepted 17 November 1988.
}

community by excluding introduced species from the seeding $\mathrm{mix}$. Even though warm-season grasses, shrubs, and forbs were seeded, the established native community was dominated by cool-season perennial grasses and fourwing saltbush (Atriplex canescens).

Williamson (1984) successfully established a seasonally balanced grassland by seeding late in spring, irrigating during the first growing season, and weighing the seed mixture in favor of warmseason species. Conventionally seeded areas produced vegetation of predominantly cool-season species. Young et al. (1983) studied use of cattle grazing to enhance native species composition. Two grazing periods did not produce a desired change in plant composition nor did interseeding with native species and grazing.

Section 515 (b)(2) of the Act "requires the operator, as a minimum, to restore the land affected to a condition capable of supporting the uses which it was capable of supporting prior to any mining, or higher or better uses of which there is a reasonable likelihood." There are few data comparing productivity of animals grazing reclaimed mined lands dominated by cool-season species with animals grazing seasonally balanced native rangeland at the same stocking rates for the same number of grazing days. Our objectives were to determine if the length of grazing use would differ between reclaimed pastures composed of vegetation with strikingly different seasonal growth patterns from native range and to quantify the effect on animal productivity.

\section{Materials and Methods}

The study was located near Center, North Dakota, on a surfacemined site previously used for a grazing intensity study (Hofmann et al. 1981, Hofmann and Ries 1988) and on adjacent unmined native rangeland. Original reclaimed and native soils are, Cabba (loam mixed, calcareous, frigid, shallow, Typic Ustorthents) and Sen (fine-silty, mixed Typic Haploborolls). Mined spoils were reshaped to near original contour and covered with approximately $10 \mathrm{~cm}$ of clay loam topsoil material.

The reclaimed area was fertilized only once with $12-12-0 \mathrm{~kg} \mathrm{ha}^{-1}$ $\mathrm{N}, \mathrm{P}, \mathrm{K}$ in spring, 1973, and seeded with a mixture of smooth bromegrass (Bromus inermis Leyss.), crested wheatgrass (Agropyron desertorum [Fisch. ex Link] Schult.), intermediate wheatgrass (Agropyron intermedium [Host] Beauv.), alfalfa (Medicago sativa $\mathrm{L}$.), and yellow sweet clover (Melilotus officinalis Lam.). The site was divided into 6 pastures with 2 replicates of 3 grazing intensities from 1976 through 1981 (Hofmann and Ries 1988). Two ungrazed exclosures, located within each pasture, provided an ungrazed check.

Exclosure size was adjusted following grazing in 1981 in order to obtain pastures with 1.86 ha grazable area. The pasture designated Reclaimed I (Fig. 1) included 0.62 ha of the formerly heavily grazed pasture combined with 1.24 of moderately grazed pasture. Lightly grazed pastures were reduced to 1.86 ha grazable area and are designated Reclaimed II. Two additional pastures with 1.86 ha grazable area were constructed on unmined native rangeland that had a condition rating of 59 (good) using SCS range condition classification technique (Dyksterhuis 1949), located 100 meters from the reclaimed site. One ungrazed-unharvested sample was 

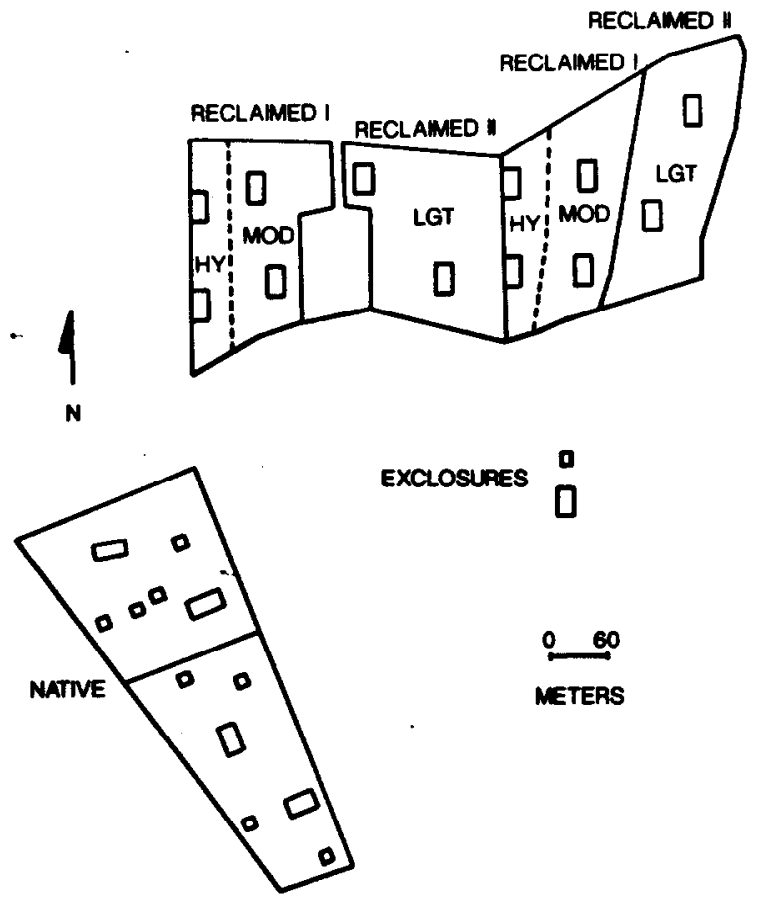

Fig. 1. Location of Reclaimed I, Reclaimed II, native pastures, and exclosure for season-of-grazing use study; and heavily (Hy), moderately (Mod), and lightly (Lgt) grazed pastures from former grazing intensity study.

obtained from each of the 6 exclosures which provided 6 subsamples from each replicate. Subsamples were averaged when analysis of variance showed no significant $(P \leq 0.05)$ difference. Two exclosures in each replicate were $15.2 \times 30.5 \mathrm{~m}$ in size while the others were adjusted in size to produce 1.86 ha grazable areas.

All pastures were grazed from 15 June through 21 September for a 96-day season in 1982. Grazing began on 25, 30, and 29 May in 1983, 1984, and 1985 and ended on 28 September and 3 and 2 October, respectively, for a 126-day season each of these 3 years.

Each pasture was stocked with 2 yearling Hereford $\times$ Simmental steers (Bos spp.) and grazed at $2.9 \mathrm{AUM} \mathrm{ha}^{-1}$. The SCS guide recommends an initial stocking rate of $1.0 \mathrm{AUM} \mathrm{ha}^{-1}$ for this site. Overnight off-water shrink starting weights ranged from 240 to 380 $\mathrm{kg}$ and averaged $325 \mathrm{~kg} \mathrm{head}^{-1}$ for the 4 years. Animals were weighed at 14-day intervals throughout the grazing season.

Thirty 10-pin point frames (Levy and Madden 1933) were read within each former heavily and moderately grazed section of
Reclaimed I, and in Reclaimed II and in native pastures each year. Each frame was randomly located and oriented by tossing a meter stick and placing the frame along side where it fell. Five frames were read within each exclosure. Basal point counts at the soil surface were recorded for live plant cover, plant species, standing or ground litter, and bare ground.

Precipitation data were collected by the National Oceanic and Atmospheric Administration at Center, North Dakota, about 2 km west-northwest of the study area. Annual June through May precipitation was used because it was better correlated to vegetation dry matter than January through December precipitation (Hofmann and Ries 1988).

Total herbage dry matter within the grazed portion of each pasture was determined by mowing six $0.3 \times 3.0 \mathrm{~m}$ strips at a $5.0 \mathrm{~cm}$ height with a sickle bar mower immediately before grazing started, the first week in August, and immediately after grazing ended. Season-long dry matter was determined in October by mowing a $0.3 \times 3.0 \mathrm{~m}$ area with the sickle bar mower under each of 6 protective cages that were randomly placed within each pasture before grazing began. One $0.3 \times 3.0 \mathrm{~m}$ area was similarly harvested within each exclosure each time vegetation was sampled.

Percent live, litter, and bare ground cover means were analyzed as a completely random design (CRD) $(P \leq 0.05)$. The WallerDuncan test was used to rank means for reclaimed and native areas. However, plant species composition was not statistically compared between reclaimed and native plant communities because they were completely different. Change in cover or plant species from 1982 to 1985 was tested using paired comparisons ( $P \leq 0.05$ ). Plant dry matter and animal gain means were tested using CRD and the Waller-Duncan test $(P \leq 0.05)$.

\section{Results and Discussion}

Annual June through May precipitation for 1981, 1982, and 1983 was about $90 \mathrm{~mm}$ above the 1914-1970 yearly average of 453 $\mathrm{mm}$ whereas 1984 and 1985 precipitation was approximately 100 $\mathrm{mm}$ below average.

Percent live plant cover on the native areas was significantly greater than on the reclaimed areas in both 1982 and 1985 (Table 1). The only measurable cover change from 1982 to 1985 was an increase of live cover on the previous moderately grazed portion of Reclaimed I. There was less litter cover and more bare ground on the Reclaimed I pastures at the start and the end of the study than on any other areas. Total ground cover (live plant plus litter) in 1985 on the previously heavily and moderately grazed portions of Reclaimed I still did not equal that of the natve site. However, all areas had less than $30 \%$ bare soil, which has been suggested as the maximum acceptable level for adequate soil erosion protection (Packer 1951, Martson 1952, Hofmann 1986).

Table 1. Percent ground cover on reelaimed and native pastures measured by basal point counts on 15 June 1982 and 28 May 1985.

\begin{tabular}{|c|c|c|c|c|c|c|c|c|c|}
\hline \multirow[b]{2}{*}{ Treatment } & \multirow{2}{*}{$\begin{array}{l}\text { Former } \\
\text { treatment }\end{array}$} & \multicolumn{2}{|c|}{ Live plant } & \multicolumn{2}{|c|}{ Litter $^{1}$} & \multicolumn{2}{|c|}{ Total } & \multicolumn{2}{|c|}{ Bare ground } \\
\hline & & 82 & 85 & 82 & 85 & 82 & 85 & 82 & 85 \\
\hline \multirow[b]{2}{*}{$\begin{array}{l}\text { Reclaimed } \\
\text { I } \\
\text { II } \\
\text { Ungrazed }\end{array}$} & & & & & & & & & \\
\hline & $\begin{array}{l}\text { Heavy } \\
\text { Moderate } \\
\text { Light }\end{array}$ & $\begin{array}{l}11 b^{2} \\
12 b \\
13 b \\
10 b\end{array}$ & $\begin{array}{l}10 \mathrm{~b} \\
17 b^{*} \\
16 \mathrm{~b} \\
16 \mathrm{~b}\end{array}$ & $\begin{array}{l}50 \mathrm{c} \\
74 \mathrm{bc} \\
84 \mathrm{ab} \\
87 \mathrm{a}\end{array}$ & $\begin{array}{l}68 \mathrm{c} \\
73 \mathrm{bc} \\
78 \mathrm{ab} \\
81 \mathrm{a}\end{array}$ & $\begin{array}{l}61 \mathrm{c} \\
86 \mathrm{~b} \\
97 \mathrm{a} \\
97 \mathrm{a}\end{array}$ & $\begin{array}{l}78 c \\
90 b \\
94 a b \\
97 a\end{array}$ & $\begin{array}{r}39 a \\
14 b \\
3 c \\
3 c\end{array}$ & $\begin{array}{c}22 \mathrm{a} \\
10 \mathrm{~b} \\
6 \mathrm{bc} \\
3 \mathrm{c}\end{array}$ \\
\hline \multicolumn{10}{|l|}{ Native } \\
\hline $\begin{array}{l}\text { Grazed } \\
\text { Ungrazed }\end{array}$ & & $\begin{array}{l}30 a \\
34 a\end{array}$ & $\begin{array}{l}30 a \\
31 \mathrm{a}\end{array}$ & $\begin{array}{l}67 \mathrm{~cd} \\
62 d\end{array}$ & $\begin{array}{l}67 c \\
66 c\end{array}$ & $\begin{array}{l}97 a \\
96 a\end{array}$ & $\begin{array}{l}97 a \\
97 a\end{array}$ & $\begin{array}{l}3 c \\
4 c\end{array}$ & $\begin{array}{l}3 c \\
3 c\end{array}$ \\
\hline
\end{tabular}

1 Contained $<1 \%$ rock.

2Means within columns followed by the same letter are not significantly different at the $P \leq 0.05$ (Waller-Duncan, test $K=100$ ).

* Significant change from 1982 to 1985 , t-test $P \leq 0.05$. 
Species composition of the reclaimed site was greatly different from the native site; therefore, meaningful species composition comparisons between reclaimed and native plant communities were not possible (Table 2). This is a major problem of measuring reclamation success by comparing mined areas reclaimed with permanent vegetation to undisturbed permanent vegetation areas. Grazing changed species composition little within reclaimed or

Table 2. Percent live plant cover by specles on rechlmed and native pastures measured by basal point counts on 28 May 1985.

\begin{tabular}{|c|c|c|c|c|c|}
\hline \multirow[b]{2}{*}{ Species } & \multicolumn{3}{|c|}{ Reclaimed } & \multicolumn{2}{|c|}{ Native } \\
\hline & I & II & Ungrazed & Grazed & Ungrazed \\
\hline & \multicolumn{5}{|c|}{ \% of live ground cover } \\
\hline \\
\hline Bromus inermis & 641 & 64 & 65 & $\mathbf{0}$ & 0 \\
\hline Medicago sativa & 24 & 20 & 21 & 0 & 0 \\
\hline Agropyron desertorum \& & & & & & \\
\hline intermedia & 8 & 8 & 8 & 0 & 0 \\
\hline Carex spp. & 0 & $\mathbf{0}$ & 0 & 18 & 23 \\
\hline Poa pratensis & 0 & 0 & 0 & $26^{*}$ & 11 \\
\hline Stipa viridula \& comata & 0 & $\mathbf{0}$ & 0 & 17 & 18 \\
\hline Agropyron smithii & 0 & 0 & 0 & 0 & 5 \\
\hline Other cool-season grass & 1 & 2 & 1 & 10 & 10 \\
\hline \multicolumn{6}{|l|}{ Warm season } \\
\hline Bouteloua gracilis & $\mathbf{0}$ & $\mathbf{0}$ & $\mathbf{0}$ & 10 & 13 \\
\hline Other warm-season grass & $\mathbf{0}$ & 0 & 0 & 2 & 7 \\
\hline Forbs & 3 & 6 & 5 & 17 & 13 \\
\hline
\end{tabular}

I Within reclaimed and native pastures, means in rows were not significantly different at $P \leq 0.05$.

Significant $(P \leq 0.05)$ increase from $10 \%$ in 1982 to $26 \%$ in 1985.

native sites (Table 2). Except for Kentucky bluegrass (Poa pratensis L.), species composition was similar for 1982 and 1985, thus only 1985 composition is presented.

Species on the reclaimed site were not of the same season of growth as the species native to the area. Throughout the study, the native site ranged from 10 to $22 \%$ blue grama [Bouteloua gracilis (H.B.K.) Lag ex. Griffiths] plus about $8 \%$ other warm-season grasses. Although we previously reported that the reclaimed site was being invaded by other species (Hofmann and Ries 1988), none have been warm-season species. The reclaimed area remained a cool-season midgrass-alfalfa community dominated by introduced species.

There was no difference in liveweight gain within years or across years. One measure of reclamation success is that production of reclaimed land equals or exceeds production of similar unmined land. Yearly gain from grazing on reclaimed mined pasture equalled gain on native pasture each year, suggesting adequate reclamation for animal production. Gains on both reclaimed and native pastures were somewhat lower than those reported by Sarvis (1941), but stocking rate was higher ( $0.95 \mathrm{vs} 1.2 \mathrm{ha}$ /steer).

Within grazing treatments, cumulative liveweight gain changed from one weighing period to the next as the season progressed (Fig. 2). Liveweight gain steadily increased from June through September and then leveled off with slight decline for late September. This is similar to the June through September yearling steer gain for native range in the northern Great Plains reported by Sarvis (1941).

No pasture differences were obtained for any weighing period except mid September. Then steers grazing Reclaimed II pastures had higher gain than steers grazing native. Since all pastures were grazed for the same number of days, the pattern for average daily steer gains (ADG) and liveweight gains was the same.

The native pasture was used as a standard for determining the season-of-grazing use since the objective was to determine if the

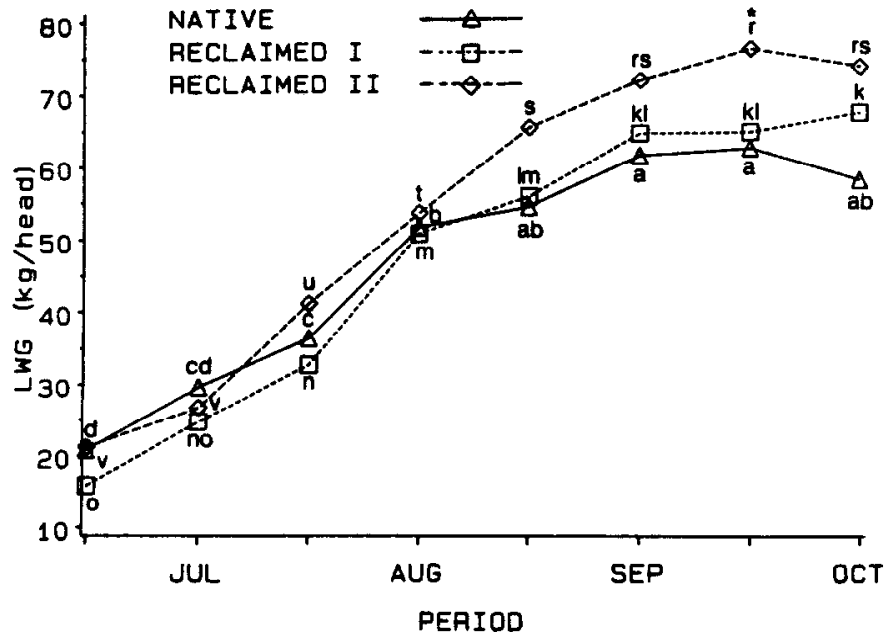

Fig. 2. Cumulative liveweight gain of steers grazing reclaimed and natve pastures at 14-day intervals throughout the grazing season (4-year average). Points on the same line labled with the same letter are not significantly different $(\mathrm{P} \leq 0.05)$. Reclaimed IIsignificantly greater than native (PS0.05).

reclaimed pastures were different. There was no evidence anytime during the study that the native pasture produced season-ofgrazing use that was superior to the reclaimed pastures.

Herbage production from the reclaimed site was greater than from the native site based on the dry matter sampled from the exclosures (Table 3). Seasonal dry matter from cages was greater

Table 3. Total herbage dry matter harvested several times per year on rechimed and native pastures. Average of 4 years.

\begin{tabular}{lcccc}
\hline \hline Treatment & $\begin{array}{c}\text { Pre graze } \\
\text { June }\end{array}$ & $\begin{array}{c}\text { Mid graze } \\
\text { Aug }\end{array}$ & $\begin{array}{c}\text { Post graze } \\
\text { Oct }\end{array}$ & $\begin{array}{c}\text { Season }^{2} \\
\text { Oct }\end{array}$ \\
\hline Reclaimed & $\cdots \ldots \ldots \ldots \ldots$ & & \\
$\quad$ Ungrazed & $3920 \mathrm{a}^{3}$ & $4690 \mathrm{a}$ & $3780 \mathrm{a}$ & $3780 \mathrm{a}$ \\
I & $2080 \mathrm{~d}$ & $2190 \mathrm{c}$ & $1480 \mathrm{c}$ & $2510 \mathrm{c}$ \\
II & $2970 \mathrm{~b}$ & $2860 \mathrm{~b}$ & $2240 \mathrm{~b}$ & $3150 \mathrm{~b}$ \\
Native & & & & \\
$\quad$ Ungrazed & $2470 \mathrm{c}$ & $2800 \mathrm{~b}$ & $2480 \mathrm{~b}$ & $2480 \mathrm{c}$ \\
$\quad$ Grazed & $1970 \mathrm{~d}$ & $1940 \mathrm{c}$ & $1560 \mathrm{c}$ & $2120 \mathrm{c}$ \\
\hline
\end{tabular}

'Current year dry matter sampled from protective cages.

2Dry matter sampled from unharvested exclosure.

${ }^{3}$ Within columns, means followed by same letter are not different at $P \leq 0.05$ (WallerDuncan test, $K=100$ ).

from Reclaimed II pastures than from Reclaimed I pasture suggesting carry-over grazing effects from the previous intensity study. Dry matter production from grazed reclaimed pastures was at least equal to that from grazed native pasture at each sampling throughout the grazing season. Thus, adequate reclamation, measured by herbage production, was achieved after 10 years of grazing use.

Seasonal dry matter sampled from cages on Reclaimed I pasture remained relatively constant during the 4 years whereas similarly protected vegetation on native pastures declined from 1983 to 1985. The lack of difference between Reclaimed I and native at the start of the study followed by a decline in dry matter on native pastures in 1984 and 1985 suggested that the native range may have been grazed at or above its productive capacity. Range condition rating declined from 59 to $52(51-75=$ good condition) primarily because of an increase in Kentucky bluegrass (Table 2). Although there were no significant differences in liveweight gain per year among pastures or years, animal gain and herbage dry matter 
trends were similar. Liveweight gains were significantly correlated to season-long dry matter, $r=.57(P<0.05)$.

Schuman et al. (1986) grazed a predominantly cool-season native plant community in Wyoming for 3 years. They reported the revegetated mined lands were successfully reclaimed and would support livestock grazing. They suggested a more direct means for determining adequacy of reclamation would be to evaluate its potential for the intended post-mining use. Laycock and Layden (1986) achieved cattle gains of 1.1 to $1.4 \mathrm{~kg} \mathrm{day}^{-1}$ summer long while grazing reclaimed lands seeded to high producing introduced species. Their data indicated potentially high animal productivity from introduced pasture species.

Based on intended use, past studies and this study suggest there is no need to have either a warm-season species component or diversity similar to premined rangeland to have comparable seasonal grazing. When grazing management practices used were the same as those recommended for grazing native range, animal performance was the same. In the northern area of the Great Plains, with average precipitation of $450 \mathrm{~mm}$ per year, cool-season, introduced grass species had the same utility of grazing use as native species. Since cool-season species are more readily established, easier to seed, less expensive to buy with a more available seed supply, we suggest they can be used to revegetate surfacemined lands for season-long-grazing use.

\section{References}

Barker, R.E., R.E. Ries, and P.E. Nyren. 1977. Forage species establishment and productivity on mined land. North Dakota Agr. Exp. Sta. Farm Res. 34:8-12.

DePuit, E.J. 1982. Cool-season perennial grass establishment on northern Great Plains mined lands: Status of current technology.p B-1-1-B-1-24. In: Proc., Mining and Reclamation of Coal Mined Lands in the Northern Great Plains Symp., Billings, Mont. 8-9 March 1982. Montana Agr. Exp. Sta. Rep. 194.
DePuit, E.J., J.G. Coenenbert, and C.L. Skilbred. 1980. Establishment of diverse native plant communities on coal surface-mined lands in Montana as influenced by seeding method, mixture, and rate. Montana Agr. Exp. Sta. Res. Rep. 163.

Dyksterhuis, E.J. 1949. Condition and management of rangeland based on quantitative ecology. J. Range Manage. 2:104-115.

Hofmann, L., and R.E. Ries. 1988. Vegetation and animal production from reclaimed mined land pastures. Agron. J. 80:40-44.

Hofmann, L., R.E. Ries, and R.J. Lorenz. 1981. Livestock and vegetative performance on reclaimed and nomined rangeland in North Dakota. $J$. Soil \& Water Conserv, 36:41-44.

Laycock, W.A., and T. Layden. 1986. Cattle production on reclaimed mined lands in northwestern Colorado. p. 162. In: Proc. Rangelands: A Resource under Siege. 2nd Int. Rangeland Cong., Adelaide, Australia. May 1984. Australian Academy of Science, Canberra, A.C.T. Australia.

Levy, E.B., and E.A. Madden. 1933. The point method of pasture analyses. New Zealand J. Agr. 46:267-279.

Marston, R.B. 1952. Ground cover requirements for summer storm runoff control on aspen sites in northern Utah. J. Forest. 50:303-307.

Packer, P.E. 1951. An approach to watershed protection criteria. J. Forest. 49:639-644.

Ries, R.E. 1982. Warm-season grasses for revegetation in the northern Great Plains. p. B-2-1-B-2-11. In: Proc., Mining and Reclamation of Coal Mined Lands in the Northern Great Plains Symp., Billings, Mont. 8-9 March 1982. Montana Agr. Exp. Sta. Rep. 194.

Ries, R.E., and L. Hofmann. 1986. Relationship of ground cover of short and midgrass communities to soil loss. North Dakota Farm Res. 44:29-31.

Sarvis, J.T. 1941. Grazing investigations on the Northern Great Plains. North Dakota Agr. Exp. Sta. Bull. 308.

Schuman, G.E., D.T. Booth, J.W. Waggoner, and F. Rauzl. 1986. The effect of grazing reclaimed mined lands on forage production and composition. p. 163-164. In: Proc. Rangelands: A Resource under Siege. 2nd Int. Rangeland Cong., Adelaide, Australia. May 1984. Australian Academy of Science, Canberra A.C.T. Australia.

Williamson, R.L. 1984. Re-establishing North Dakota grasslands after mining with emphasis on seasonality and use of native species. J. Soil \& Water Conserv. 39:387-391.

Young, S.A., R.B. Rennick, and P.L. Plantenbers. 1983. Use of grazing cattle during post seeding management of revegetated minespoils. Final Report. Montana Agr. Exp. Sta. 